\title{
3. John Howard, weapons of mass destruction and the public's right to know
}

\section{ABSIRACI}

In March 2003, Australia went to war in Iraq to find and remove Saddam Hussein's weapons of mass destruction (WMD). None were found. An Australian Parliamentary Committee concluded:

The case made by the government was that Iraq possessed WMD in large quantities and posed a grave and unacceptable threat to the region and the world, particularly as there was a danger that Iraq's WMD might be passed to terrorist organisations. This is not the picture that emerges from an examination of the assessments provided to the Committee by the Australian Office of National Assessments (ONA) and the Defence Intelligence Organisation (DIO).

This commentary examines what was the threat to Australia, what the government said it was, and what the Australian intelligence agencies said it was. It also describes the media reaction and government response to the Parliamentary Committee Report and discusses whether the government explained its position honestly.

Keywords: intelligence, Saddam Hussein, terrorism, weapons of mass destruction

RICHARD MILLS

Foreign policy analyst

\section{Introduction}

TN MARCH 2003, Australia went to war in Iraq to find and remove Saddam Hussein's weapons of mass destruction (WMD). ${ }^{1}$ None were

found. In 2004, the US Iraq Survey Group found that Saddam had had no WMD for at least a decade before the war in 2003, and there was no evidence that he wanted to supply WMD to terrorist groups. ${ }^{2}$ 
In Australia, an inquiry by the Parliamentary Joint Committee on ASIO, ASIS and DSD (the Jull Committee) ${ }^{3}$ considered the nature, accuracy and independence of Australian intelligence on Iraq, and the accuracy and completeness of the presentation of that intelligence to the Australian people. Its report was released on 1 March 2004. The Jull Committee concluded:

The case made by the government was that Iraq possessed WMD in large quantities and posed a grave and unacceptable threat to the region and the world, particularly as there was a danger that Iraq's WMD might be passed to terrorist organisations. This is not the picture that emerges from an examination of the assessments provided to the Committee by the Australian Office of National Assessments ${ }^{4}$ and the Defence Intelligence Organisation. (Jull, 2003, p. 93)

The Prime Minister, John Howard, claimed in Parliament the most important thing the Jull Report did was that it 'completely denied the 12-month claim of Labor (the Opposition Party at the time) that we went to war based on a lie' (Hansard, 1 March 2004, p. 25391). 'What we did was justified by the intelligence available to us. I certainly didn't exaggerate things' (quoted in The Australian, 1 March 2004). The Foreign Minister said the report 'vindicates the government's use of intelligence in making the case for action against Iraq' (Hansard, 1 March 2004, p. 25391).

The purpose of this commentary is to examine some of the print media's reaction to the Jull Report, and to the government's response to the report. It is based on reports in two national newspapers and the main newspapers in Canberra, Melbourne, and Sydney_-The Age, The Australian, The Australian Financial Review, The Canberra Times and The Sydney Morning Herald -in the days following the release of the Jull Report.

The commentary is in three parts. It looks first at four intelligence-related issues: the threat of WMD to Australia, assessment of the consequences of going to war, political interference in intelligence assessments and the reasons for going to war. The second part looks at the scope and nature of the press coverage, particularly of those four issues, and the final part considers the accuracy and honesty of the government's explanations.

\section{What was the threat to Australia?}

What did the government say it was, and what did the Australian intelligence 
agencies say it was? How serious, likely and urgent was it?

Prime Minister Howard said in Parliament in early 2003 that 'Iraq's continued defiance of the UN and its possession of CBW (chemical and biological weapons) and its pursuit of a nuclear capability poses a real and unacceptable threat to the stability and security of our world' (Hansard, 3 March 2003, p. 10642). He also said, 'possession of chemical, biological, or nuclear weapons by terrorists would constitute a direct, undeniable and lethal threat to Australia and its people' (Hansard, 18 March 2003, p. 12506). Foreign Minister Downer added that 'Saddam Hussein does have proven links to terrorism. The combination of his weapons of mass destruction and the determination of terrorists to acquire them is for this government an unacceptable threat' (Hansard, 18 March 2003, p. 12532).

Howard's sources of information were apparently not Australian but overseas intelligence agencies. He said 'the British JIC (Joint Intelligence Committee) judged that Iraq has a useable CBW capability, which has included recent production of $\mathrm{CB}$ (chemical and biological) agents.... The analysis provided by the Director of the US Central Intelligence (Agency) reached similar conclusions, namely Iraq...has begun renewed production of $\mathrm{CW}$ (chemical warfare) agents' (Hansard, 3 March 2003, p. 10645).

A year later, the Jull Report noted that the Australian intelligence agencies had made little assessment of the immediacy of the threat, but ONA(Office of National Assessments) had said in March 2001 that the threat was less than it had been in 1991 (Jull, 2003, p. 40). The report also said that from February 2000 to September 2002, ONA and DIO (Defence Intelligence Organisation) had agreed that 'while there is a capacity to restart programmes, chemical weapons and biological weapons, if they exist at all, would be in small quantities' and that Saddam Hussein's 'capacity to use his weapons is low, and his willingness to use them is...defensive' (ibid., p. 31).

DIO doubted there had been any CBW after 1991 (Jull, 2003, p. 98) and said it would not have judged that the threat was 'real and unacceptable' (ibid., p. 95). After September 2002, ONA 'tends to be much more definitive ... and assertive' (Jull, 2003, pp. 32-33), saying that it was 'highly likely' WMD existed, but still describing them as 'small stocks' (ibid., p. 98).

So according to the Australian intelligence agencies, although WMD probably existed, their significance in terms of capability and intention was that the threat was not serious, likely or imminent. 


\section{What was the assessment of the consequences of going to war?}

Howard said on 20 March 2003 that 'we believe that so far from our action in Iraq increasing the terrorist threat, it will, by stopping the spread of chemical and biological weapons, make it less likely that a devastating terrorist attack will be carried out against Australia'. ${ }^{5}$ ONA did not tell the Jull Committee if it had made a judgment on whether the war would lessen the terrorist threat to Australia, although the British Joint Intelligence Committee's view to the contrary had been made in February 2003 (Jull, 2003, p. 97). Howard did not mention that in his public statements.

A later Australian report said that there had been no national intelligence assessment that looked at the big picture, and 'little intelligence assessment [of] the strategic cost implications for Australia of contributing to military action against Iraq, the likely strategic costs and issues involved in postSaddam Iraq, and the impact of military action on the safety of Australia and Australians' (Flood, 2004, p. 27).

So as far as the Jull Committee was concerned, there was no evidence of intelligence in support of planning for Australian involvement in a post-war Iraq.

\section{Was there political interference in the preparation of assessments?}

DIO and ONA told the Jull Committee no, and its report said 'the committee has received no evidence that political pressure was applied to the agencies'. However, it found unpersuasive ONA's explanation for its sudden assertiveness in September 2002 (Jull, 2003, p. 54).

\section{To what extent was intelligence the determinant in going to war?}

The Prime Minister had based his arguments on going to war on the existence of WMD in Iraq, their magnitude, and particularly the concern that they might fall into the hands of terrorists. In a major speech, he said: 'And if terrorists ever get their hands on weapons of mass destruction that will, in my very passionate belief and argument, constitute a direct, undeniable and lethal threat to Australia and its people, and that would be the ultimate nightmare not only for us but for other peoples in other nations. That, more than anything else, is the reason why we have taken the stance we have and it is the reason why we believe that Iraq should be effectively and comprehensively disarmed'6 (Address to the National Press Club, 14 March 2003). 
But were there other reasons, and if so, how important were they? The Jull Committee's terms of reference did not include any consideration of the policy-making process that led to the decision to go to war other than the extent to which intelligence on WMD had been a determinant (Jull, 2003, p. 82). However, the committee pointed out that the evidence in support of the government's position was not based solely on intelligence, but also on 'a mixture of historical experience, first principle hypotheses, deductive logic, assumption and assertion' (ibid., p. 89). It also noted that DIO said it had made a judgment that 'the US was committed to military action against Iraq, [and] ...that was ...independent of the intelligence assessment' (ibid., p. 81).

Some had argued for regime change because Saddam was a monster, and that regime change would moderate forces in the Middle East making more likely both a solution to the Israel/Palestine problem and the reduction/eradication of terrorism. Howard had not adopted that argument. In fact, he rejected it. 'I would have to accept that if Iraq had genuinely disarmed, I couldn't justify on its own a military invasion of Iraq to change the regime. I've never advocated that' (Address to the National Press Club, 14 March 2003).

He had not hidden, however, the importance to him of the security alliance with the United States. ${ }^{7}$

\section{The scope and nature of the press coverage}

On 2 March 2004, the press gave page one attention and considerable space to the Jull Report and the government's responses. In general, their articles, opinion pieces and editorials covered all the main criticisms the report had made. Most papers pursued the issues on March 3. The quotes in the following paragraphs come from the editions on 2 and 3 March 2004. It is beyond the scope of this commentary to analyse the emphases and differences in interpretation that appeared among and even within the different newspapers, and that is certainly a topic worth pursuing. However, the following description does give a reasonable coverage of the issues treated and the conclusions reached.

The Age's main point made by Mark Forbes, its foreign affairs correspondent, was that 'the case made by the Howard Government for war against Iraq was not fully supported by advice from its own intelligence agencies'. The headlines were critical of the Prime Minister- 'Doubt cast on Howard's reasons for Iraq war' and 'Tough questions remain unanswered despite PM's 
claims of exoneration'. One article focused on ONA's changing advice: 'The key intelligence agency that advises Prime Minister John Howard suddenly and inexplicably hardened its view that Iraq had WMD six months before war began.' This theme was repeated and ONA compared with DIO. 'Unlike the DIO, which continued to state that there was no evidence that Iraq had resumed biological or chemical weapons production, ONA extrapolated from untested intelligence, the Committee said.' The Age's international editor commented that 'the Jull Committee has highlighted gaps and exaggerations in the case put to the public' and that it 'found the Howard government was more measured and cautious in tone than its counterparts in Britain and the US.' The Age did not discuss the relationship between the intelligence agencies' forecasts and the consequences of invasion.

The Australian's page 1 headline was 'PM's spin sexed-up Iraq threat' and the main point, as seen by Patrick Walters, was that the Howard government had exaggerated the threat of WMD because it based its case on flawed US and British intelligence assessments 'rather than the more cautious, yet still overstated, analysis presented by Australia's key intelligence agencies.' Cameron Stewart focused on ONA's changed emphasis in September 2002, saying that Jull made damning reading for those inside ONA. However, he also said that Jull 'reaches the equally damning conclusion that the Howard government's rhetoric on Iraq exceeded the evidence provided to it by its own two intelligence agencies'.

Remarkably, The Australian's editorial nevertheless said that the Jull Report had 'found the Prime Minister and his colleagues did not pervert the advice of their intelligence advisers'. It did acknowledge that 'the government's case for war was stronger than the language used by the intelligence agencies,' but offered the curious explanation that 'the decision to fight had to be expressed in political terms, not the careful language of bureaucrats'.

Three of The Australian's writers looked at the relationship between intelligence and the decision to go to war. Patrick Walters wrote:

The Prime Minister did not go to war because of the intelligence presented on the threat posed by Saddam. In the end it was not WMD but the pull of the US alliance that proved irresistible to Howard in determining that we join the US-led coalition in invading Iraq. But, as this report makes abundantly clear, Australians were entitled to 
conclude from the case presented by the Howard Government that the WMD threat posed by Iraq was immediate and pressing.

Paul Kelly emphasised that 'the war was not, repeat not, driven by intelligence'. Matt Price observed that the Prime Minister 'betrays not a jot of doubt the war was justified, albeit that his reasons for signing on flipped and flopped like laundry in a cyclone'.

The Australian Financial Review's Laura Tingle reported that the Jull Report said 'government ministers' public statements were "more strongly worded than most of the Australian intelligence community's judgments" and were incomplete in documenting intelligence unfavourable to the case for war'. She quoted the Jull conclusion about the government's statements not matching the evidence from its own intelligence agencies and quoted Kim Beazley (the leader of the Labor Opposition) in Parliament saying the exaggerations, the sense of immediacy, was the work of politicians outside the intelligence advice they were being presented.'

She also pointed out that Howard and Downer used the finding of no evidence of political pressure to claim that the report, 'despite its damning findings, vindicated the government's use of intelligence in the lead-up to the war'. The Australian Financial Review's editorial focused on ONA's change of tone in September 2002.

The headlines in The Canberra Times were 'PM talked up war' and 'Case not backed by our spy bureaus'. Ross Peake commented that 'the gap between his presentation and the assessments is the core finding'.

The editorial in The Canberra Times was almost the only article to look at the issue of effective planning for a post-war Iraq. It said the benefits of supporting the US had to be weighed against other considerations 'of how Australia's actions might affect Australia's own interests generally or in our neighbourhood' and 'whether the US strategy was likely to be effective'. It concluded that 'John Howard seemed to address neither'.

The editorial also considered the reasons for going to war. It said that the report made clear that 'Australia did not enter the war against Iraq on the basis of a brief that Saddam Hussein's possession of [WMD] constituted a clear and present threat to Australia's interests... It was always apparent to most observers that Australia's decision to get involved owed most to a desire to stand alongside the United States'. 
Finally, the editorial advised the public to be sceptical the next time the government cited vague intelligence advice about things like terrorism, noting that it was almost incredible to assume that the government would honestly share with the public the advice it had received.

The Sydney Morning Herald's Tom Allard began with 'the Federal Government selectively used alarming overseas intelligence to bolster its case for war against Iraq, but did not doctor-or "sex up" reports on the threat'. He continued, 'government claims that Iraq posed a grave and immediate threat were not backed by Australian intelligence assessments' and repeated 'government statements were worded more strongly than Australian intelligence judgments because they were based on British and US assessments'.

Other articles, by Peter Hartcher and Tom Allard, covered the absence of imminent threat, the conflict between Howard's and the UK Joint Intelligence Committee's assessments about the reduction of the terrorist threat, the 'substantial hardening' of the ONA assessment in September 2002, and the US alliance being the main reason for going to war. An editorial focused on the need for independence and impartiality of ONA. Tom Allard returned to this issue on March 6.

Specialist commentator and former senior Defence bureaucrat Hugh White noted that analysis of policy advice was beyond the committee's terms of reference but claimed that the policy departments had been mute on how to deal with whatever the threat was and what the costs and consequences of the invasion would be: 'The government had already made up its mind, and their opinion was not called for or offered.' He asked delicately, 'is that how we want the system to operate?'

\section{The accuracy and honesty of the government's explanations}

The Australian government has blamed poor intelligence for the decision to go to war. The government did not say that US and UK assessments differed from Australian judgments or that there were differences between ONA and DIO. It did not say that DIO's judgments on the significance of the threat were pretty much right.

Despite all that, and despite the critical headlines in all the papers, the outcome of the Jull Report and the commentary on it was summed up in the headline to one of Paul Kelly's articles: 'Caught by facts, but PM wins the politics' (The Australian, 3 March 2004). Why was this? At least six 
well-known techniques of media management (or manipulation, depending on your point of view) limited the damage to the government.

\section{Selectivity}

The government naturally chose to focus on the points that served their purposes and ignored the others. Is this reasonable? Greg Sheridan had thought so. 'The most you can say is that Blair (and Howard and Bush) presented information they thought to be true in a fashion designed to be supportive of their general argument for war. There's nothing wrong with that' (The Australian, 31 January 2004).

\section{Denial of fact}

Almost universally, the media identified a major criticism in terms like "the Jull Committee has highlighted gaps and exaggerations in the case put to the public' (The Age, 3 March 2004). The Prime Minister simply replied: 'I certainly didn't exaggerate things' (quoted in The Age, The Australian and The Sydney Morning Herald, 1 March 2004).

\section{Deception}

Howard had claimed that ONA had vetted his speeches. ${ }^{8}$ In fact, ONA had only confirmed 'the accuracy of the references to intelligence information' (Jull, 2003, pp. 93-94), which apparently meant that ONA confirmed the accuracy of the American and British quotes that Howard used, not that the assessments themselves were actually correct. Mark Forbes wrote, 'astoundingly, given the Prime Minister has repeatedly stated that the ONA endorsed the contents of his Iraq speeches, the report reveals it did not examine the accuracy of claims coming from overseas agencies'. Tom Allard wrote that 'ONA checked the use of foreign material to ensure it was quoted accurately, but did not scrutinise the content of the claims to ensure they were true.'

\section{Fabrication}

The Canberra Times quoted the Prime Minister saying that the report 'completely denied the 12-month claim of Labor that we went to war based on a lie' but went no fr ther. Matt Price in The Australian and Alan Ramsey in the Sydney Morning Herald both pointed out that it did no such thing.

\section{Deliberate misquoting}

Howard said: 'The committee found that the statements that I and my colleagues had made were very moderate, particularly compared with 
statements made elsewhere' (Hansard, 1 March 2004, p. 25391). This is not the same thing as reported by Tony Parkinson, The Age's international editor: 'The Jull Committee...found the Howard Government was more measured and cautious in tone than its counterparts in Britain and the US'. ${ }^{9}$ It is of course possible to be more moderate than others while still exaggerating the threat.

\section{Bland deflection}

When asked about the unexplained hardening of ONA's assessments, Downer said he had not noticed any significant difference in the reporting (The Age, 3 March 2004).

\section{Conclusion and the public's right to know}

Some people think foreign affairs and security matters are too arcane and complicated to be treated adequately in the media. Even allowing for limitations of time and space and other restrictions on comprehensive and objective reporting, the coverage of the Jull Report was good.

However, it is in the nature of things that media attention is very hard to sustain. Not many seemed to remember that a year before the Jull Report's release an ONA officer, Andrew Wilkie, resigned over the government's presentation of the intelligence and the policy, saying that Iraq did not pose a threat to anybody. He had said that the Iraqi military was very small, their WMD programme was fragmented and contained, and there was no hard evidence of active co-operation between Iraq and Al Qaeda. Because he had the courage to say so in public he was subjected to a disgraceful campaign of denigration, even though he was right.

In March 2004, the excitement did not last long. Howard's quick agreement to Jull's recommendation to have a broader inquiry into intelligence matters took the political heat out of the other findings.

There was no great sense of indignation, let alone outrage about misleading or unfactual statements by the Prime Minister or Downer, perhaps demonstrating that the media and the public accept after long experience that this is how politicians behave and the electorate does not really care very much. On the other hand, WMD joined the litany of examples of the Howard Government's deceptions, which perhaps had a cumulative effect by the time of the election in 2007.

It is most unusual for any government to allow intelligence matters to 
be aired in public. The Jull Report is a significant exception and prompts the question: why cannot more intelligence assessments be made publicly available? (After deletion of information that would compromise sources and methods, of course). The contents of the intelligence judgments revealed by the Jull Committee were in themselves no different from those held publicly by others. In this, as in many other instances, the government did not wish to display the fact that their decisions did not reflect the views of their expert advisers.

Writing in November 2007, there seems to be no military solution in Iraq. If it is so important, should Australia be committing more money and troops? If our troops should withdraw when there is a reasonable chance that Iraq can look after itself, when will that be? Howard has not told us what he thought about this. I wonder if the Australian Intelligence Community has offered an opinion (or more than one), and if Rudd will tell us what it is. More broadly, what institutional changes will Rudd pursue to enable the people to be better informed about significant policy options? A genuine commitment to more open government backed by specific improvements, such as a reduction of the constraints in the Freedom of Information legislation, would be a good start.

\section{Notes}

1. WMD usually refers to Chemical and Biological Weapons (CBW) and nuclear weapons.

2. The final report of the Iraq Survey Group can be seen at http://www.globalsecurity. org/wmd/library/report/2004/isg-final-report/

3. ASIO is the Australian Security Intelligence Organisation, ASIS is the Australian Secret Intelligence Service, and DSD is the Defence Signals Directorate. The Committee was chaired by David Jull, a member of the Liberal Party, and included former Labor Defence Ministers Kim Beazley and Robert Ray.

4. The Office of National Assessments (ONA) analyses information from all sources on the external influences on Australia's interests. It reports to the Prime Minister.

5. Prime Minister's Address to the Nation, 20 March 2003. See http://pandora.nla. gov.au/pan/10052/20030521-0000/www.pm.gov.au/iraq/index.html

6. Prime Minister's Address to the National Press Club, 14 March 2003. See http:// pandora.nla.gov.au/pan/10052/20030521-0000/www.pm.gov.au/news/speeches/ 7. See, for example, his speeches in the Parliament on 4 February and 18 March 2003 (pp. 10650 and 12508) and to the National Press Club on 14 March 2003.

8. See, for example, Hansard, 1 March 2004, p. 25397. 
9. On the ABC's 7.30 Report that night, Howard dropped the qualification altogether, saying that the Committee 'found that the statements I and my colleagues have made were very moderate.' Sadly, Michael Brissenden responded: 'True enough.'

\section{References}

Barker, G. (2003). Sexing it up: Iraq, intelligence and Australia. Sydney: University of New South Wales Press.

Barton, R. (2006). The weapons detective. Melbourne: Black Inc. Agenda.

Flood, P. (2004). Report of the inquiry into Australian intelligence agencies. Canberra: Commonwealth of Australia.

Garran, R. (2004). True believer: John Howard, George Bush and the American alliance. Crows Nest, NSW: Allen and Unwin.

Parliamentary Joint Committee on ASIO, ASIOS and DSD (2003). Intelligence of Iraq's weapons on mass destruction. Canberra. For brevity, this report is referred to in the text as 'Jull, 2003', after the name of the chairman of the committee.

Wilkie, A. (2004). Axis of deceit. Melbourne: Black Inc. Agenda.

Woolcott, R. (2003). Truth and accountability in public policy: implications for Australia's foreign policy. Sydney: Asia-Australia Institute, University of New South Wales.

Richard Mills is a former member of the Senior Executive Service of the Australian Public Service. His positions included head of the Cabinet Office in the Department of Prime Minister and Cabinet, Chief of Staff to the Minister for Defence and Deputy Ombudsman. In recent years, he has taught Australian foreign and defence policy and Australian public policy at Sydney University and Macquarie University.

rhmills@bigpond.net.au 